\title{
8. Exile as Doom and Revenge: Hermann Ungar
}

There is a fine line between anxiety and doom. When anxiety becomes unmanageable, a feeling of doom arises. However, aesthetically a stance can be created from doom - "noble infirmity." This happens in the work of another Moravian by birth, who is much less known than the authors already discussed, Hermann Ungar (b. 1893 in Boskovice, d. 1929 in Prague). Ungar is a dark author whose work takes the sense of exile as far as doom, or noble infirmity, in a way somewhat similar to Marcel Proust. Ungar, unlike Proust, though, is fascinated by extremely abusive behavior and the revenge that can result from such treatment. Interestingly, Ungar's work was immediately noted in France, yet rather neglected in Germany and Czechoslovakia.

Ungar grew up speaking German and Czech and was educated in German, as most Jews in the Czech lands were. He played a significant role in Czech Zionism and confronted the Catholic antisemitic and superstitious bigotry common in the Moravian countryside. During his adolescence, the Hilsner trial ${ }^{34}$ was still fresh in peoples' minds and precipitated attacks on Jewish shops and homes in his area. During WWI, he fought on the Russian front and was wounded; after the war, he lost his interest in Zionism and devoted himself to supporting the newly formed Czechoslovakia and its democratic ideals. He died prematurely in 1929 at the age of thirty-six of appendicitis. His family was later deported to Nazi concentration camps, where they perished, except for his sister who

34 Leopold Hilsner was falsely accused of murdering a Czech girl for ritualistic reasons (1899/1900); he was defended by Thomas Garrigue Masaryk, the future first president of Czechoslovakia. 
left for Palestine and committed suicide in 1946 after hearing of her family's fate.

Ungar's literary work was published in editions that were soon forgotten and he was unacknowledged for decades. While Thomas Mann and other major writers and publishers valued his work very highly, Max Brod, who canonized the Prague Circle, on the other hand, mentions Ungar only in passing. In his native land he was published only in 2002-2006 by the American Twisted Spoon Press. Diane George writes:

He should be considered not only in the context of other Czech German writers (Rilke, Werfel, Paul Leppin) and not only as a lesser or lesser-known Kafka, but also alongside the Austrian Leopold von Sacher Masoch. Many of Ungar's motifs could justly be called masochistic-strippings, beatings, humiliations-but a more important point of comparison is Ungar's and Masoch's use of suspense. ${ }^{35}$

Ungar's Boys and Murderers (1920) and The Maimed (1922) are stories of oppressed and abused boys who turn into depraved men. In Boys and Murderers, the author uses this situation to dissect murderous behavior, dark parts of the human psyche, depravities of the heart, and delusions of the mind. Each story presents a twisted and sadistic individual revenging himself for his lack of love in his early life and his resulting sense of powerlessness and loneliness. Ungar's protagonists project their accumulated hatred onto innocent individuals. Deviant sexual behavior, a disgust for female sexuality, the torture of animals, and the abuse of women are all part of their behavior. In the story "A Man and a Maid," a young man continues his depraved, lonely, heartless, and cruel life in America despite his becoming a successful businessman. In "Story of a Murder," Ungar shows how the contempt and abuse of his father, as well as society, leads a boy to become a murderer. Ungar also brings up the irresistible urge to torture and kill that such men have towards the weak (including animals) or handicapped. Hermann Ungar, Chicago Review 53, nos. 2/3 (Autumn 2007): 206. 
In the novel The Maimed, the main hero, Franz Polzer, is just a very frightened individual, who subconsciously replays situations from his childhood, a time when he was deprived of power, dignity, and love. This causes a lack of trust in people and irrational fear of them. His sexuality, a source of shame, leads him to a desperate search for security, which he manifests by endlessly counting his meager possessions. The inability to feel any true feelings and act on them is a gruesome premonition of the horrific civilizational disease that gripped Europe and especially German society in the twentieth century. It is reminiscent of Kafka's absurdist story "In the Penal Colony." Even though America might present a certain freedom or productive way of life to one of Ungar's antiheroes, it really does not free him from his inner hell, as he continues to pursue his destructive lifestyle even there. Compassion is nonexistent in Ungar's protagonists. Thus, when compared with Werfel's antipatriarchal story, we see that Ungar depicts essentially the same issue, but carries it much further in terms of its ominous implications and consequences.

Ungar's and Kafka's protagonists achieve only very limited inner freedom by removing themselves from the causes of their discomfort. While Kafka's writing is abstract and profoundly polysemic, Ungar's writing describes credible, if exaggerated, oppressive human situations. Perhaps a reason for Kafka's enormous world renown is the fact that his stories, despite their darkness, have a humorous streak and can be applied to a broad spectrum of situations, while Ungar's work is rooted in a highly specific environment with protagonists that are naturalistically depicted and denies the possibility of redemption. Ungar's protagonists are marginal and their behavior distasteful, yet this very same behavior became mainstream only a few years later as the Nazis dominated Europe. 